\title{
SECURITY ASPECTS OF FOSTERING THE DOMINANCE OF POLITICS OVER EDUCATION IN BOSNIA AND HERZEGOVINA
}

\section{Nerma HALILOVIĆ-KIBRIĆ}

\section{Abstract}

Reason(s) for writing and research problem(s): Bosnia and Herzegovina offers a unique opportunity to examine how education is evolving and adapting in the context of state-building and the extent of efforts made in a still ethnically divided society. It seems very important to examine the role that politics have played in education in Bosnia and Herzegovina throughout history, and the consequences that certain attitudes have had on the current security situation in the country.

Aims of the paper (scientific and/or social): This paper aims to determine the consequences of fostering the dominance of politics over education on current relations among citizens in post-conflict Bosnia and Herzegovina, and unveil the impacts of such relations on national security.

Methodology/Design: The following methods were used: analytical-synthetic methods, hypothetical-deductive methods, and also axiomatic and comparative methods and, from the data collection perspective, the method of document content analysis, as well as the case study method.

Research/paper limitations: The main limitation of this paper is the impossibility to provide a more detailed analysis for the period of 1992-1995. Namely, there are very few available materials that testify to the topic of education in this period.

Results/Findings: The results show that all authorities in the observed periods were aware that the ease of their rule and the repetition and maintenance of the ruling relationship depend to a small extent on the character of education. As a result, they carefully selected and prepared curricula and designed educational programs according to their preferences, thus proving the direct impact of politics on education.

General conclusion: The impact of politics on education in all three analysed periods of development of education in Bosnia and Herzegovina was confirmed. Given the persistent ethnic polarization, all countries in the region could make fair use of the Council of Europe's expertise, primarily in the areas of human rights, democratic citizenship and cultural diversity. 
Research/paper validity: In scientific terms, the research is justified by the need to point out the consequences that the politicized, segregated, fragmented and decentralized education system in Bosnia and Herzegovina has on security issues.

\section{Key words:}

security, education, politics, Bosnia and Herzegovina

\section{INTRODUCTION}

Bosnia and Herzegovina, a multi-ethnic and multi-religious state, has been in the focus of peace and conflict research since its inception in the wake of the Dayton Accords that ended the Bosnian War, which lasted from April 1992 to December 1995 (Kivimaki, Kramer \& Pasch, 2012). A quarter of a century after the end of the violent conflict, it seems that country itself is still unprepared to become a self-sustaining, functioning state, mostly since none of the three dominant ethnic groups (termed 'Constituent Peoples') - Bosniaks, Serbs and Croats - appear to accept Bosnia and Herzegovina $(B \& H)$ in its present form. Although the state should strive for reform processes and European Union accession, it remains paralyzed by many socio-political and economic challenges, which pose a significant hindrance to much-needed progress. The conflict narrative of $\mathrm{B} \& \mathrm{H}$ is concentrated on the 1992-1995 war. However, the origins of the use of education to spread intolerance are rooted in earlier historical periods.

According to Smith (2005), education concerning conflict and post-conflict areas can be viewed from several perspectives. First one is a political perspective, as a powerful tool for developing a particular ideology. Within this perspective, education can be used to develop liberal ideas, build a nation, and, in extreme cases, be a part of a process of indoctrination. Second, education can be seen as an instrument for creating and disseminating the knowledge and skills needed for economic development. Third, education is a mean by which social and cultural values are passed down from generation to generation, and, depending on the values in question, can result in the passing-on of certain negative stereotypes or attitudes that explicitly or implicitly call for hatred or violence, or even directly generate violence. Furthermore, Bush and Salterelli (2000) in their research have identified specific examples of abuse of education: education being used as a weapon in cultural repression of minorities (unequal access to education or the use of education to dissolve language, tradition, art, religious practice and cultural values); separate education systems being used to maintain inequalities among groups in society; denial of education as a weapon of war; manipulation of history and textbooks for political purposes; and education being used to instil attitudes of superiority, for example, through a description or portrayal of other people or nations as less valuable. As it will be presented in this paper, it can be 
noticed that most of the above items are unfortunately evident within education in B\&H.

Bosnia and Herzegovina faces a multitude of security issues, and this has been highlighted for years by numerous international institutions and organizations. What is particularly worrying and burdensome for the reality of B\&H is the fact that the state has made minimal progress in post-war and social reconciliation. Such a situation gives rise to significant problems related to governance, the rule of law, and democratic accountability. ${ }^{1}$ The analysis of security risks conducted by the Atlantic Initiative and the Democratization Policy Council in the period from spring to autumn 2011, assessed several factors affecting the potential for inter-ethnic violence and the resurrection of armed conflict in $\mathrm{B} \& \mathrm{H}$. The analysis showed an increasingly frequent questioning of the state of B\&H (Azinović, Bassuener \& Weber, 2012). Some of the critical areas that could lead to the escalation of ethnic violence and the prolongation of the crisis that emerged in the 1990s highlighted by the authors include: incitement of political rhetoric and hate speech, by both political elites and the media; weak capacities of state institutions; economic crisis and polarization of the extremely rich and those on the brink of extinction, which can lead to social unrest; a security sector that lacks uniformity and coordination across all levels; a judicial system within which political influence has been proven to be exerted on several occasions; dissatisfied youth, who express their frustrations at football matches, but also through juvenile delinquency, hate speech and hate incidents; a returnee population whose exercising of their rights without the interference of security services is rare; and Islamist radicalization and terrorism. One somewhat disappointing aspect of this report is the fact that the authors referred only to Islamic radicalism, thus undeservingly ignoring other radical ideologies that undeniably also pose a threat to the security B\&H and its citizens. ${ }^{2}$ Also, a fascinating critical area presented by the authors is that of young people who express their frustrations at football matches, but also through juvenile delinquency, hate speech and hate crimes. This speaks in favour of the thesis that the manifestation of

\footnotetext{
${ }^{1}$ In the 2015 OECD report entitled "States of Fragility 2015, Meeting Post-2015 Ambitions", B\&H is included in the group of the 50 most unstable countries in the world. To measure instability, the OECD put forward a model consisting of five measures: violence; access to justice for all; effective, accountable and inclusive institutions; economic inclusion and instability; capacities for prevention and adaptation to economic, environmental crises, and disasters. The full report is available at http://www.oecd.org/dac/states-of-fragility-2015-9789264227699-en.htm, accessed 28 October 2019.

2 The gathering of members of the Chetnik Ravna Gora movement in Višegrad in March every year is just one of a series of examples.
} 
such phenomena among young people must be controlled and, if possible, prevented through the education system.

However, a study conducted by The Organisation for Economic Co-operation and Development (OECD, 2015) reported that the basic function of the curriculum in B\&H is political, especially when it comes to history and mother tongue. The reality of B\&H is determined by the post-conflict atmosphere, ethnonational incidents, the country's economic weakness, territorial divisions, and the coexistence of three major ethnic groups. Political leaders use this situation to propagate national ideas by which they seek to instil fear within their ethnic group to satisfy their interests through the fomenting of nationalism.

Abazović begins his book State Security: Introduction and Basic Concepts (2012) with a discussion of national security, stating that the security of a country is its "primary systemic activity", in essence "a state in which a balanced physical, spiritual, social and material survival of the individual and the social community with other individuals, social communities and nature". However, people in Bosnia and Herzegovina, as in other parts of South-eastern Europe, are undergoing a process of transition, within which contradictory value systems influence them. On the one hand, there are the collective and individual values that currently define them, which, together with democracy, have become an integral part of today's Bosnia-Herzegovinian society. At the same time, on the other side, there is a revival of traditional values that were discouraged during the time of the Socialist Federal Republic of Yugoslavia ${ }^{3}$ Therefore, the question arises as to how to strike the balance that Abazovic mentions in his definition and whether this is even possible.

The primary aim of this paper is to answer the question: Can elements of fostering the dominance of politics over education be found throughout the history of education in Bosnia and Herzegovina, and what are the consequences of such an attitude? Bearing in mind that in qualitative research, the subjects of study must be viewed developmentally and from the perspective of their layered historical dimension (Halmi, 1999, p. 29), this paper provides an analysis of the three phases of the development of Bosnia-Herzegovinian society, with particular reference made to education, and the impact and influence of politics upon it.

\footnotetext{
${ }^{3}$ Also known as the Federal People's Republic of Yugoslavia in the period from its establishment in 1945. until the constitutional reforms of 1963.
} 


\section{ANALYSIS OF THREE PERIODS IN THE HISTORY OF BOSNIA AND HERZEGOVINA'S EDUCATION}

What is very important for this analysis is that the current events and the current situation in $\mathrm{B} \& \mathrm{H}$ directly correlate to the turbulent past of the country, but also of the entire region. Therefore, it seems very important to analyse three crucial periods in the history of $\mathrm{B} \& \mathrm{H}$ 's education, in order to better and more clearly understand the current security situation and to try to find the roots of the problems facing B\&H today. Davies (2004) concluded that an analysis of education in post-conflict areas before, during and after the conflict is of great importance in gaining an insight into the relationship of education to the conflict itself, and the consequences of such a relationship, as well as to determine opportunities for future action. By the above, the following table will serve as a basis for considering the three defined phases:

Table 1. Recent historical phases in B\&H (Kivimaki, T., Kramer, M. and Pasch, P. [2012]. The Dynamics of Conflict in the Multi-ethnic State of Bosnia and Herzegovina Country Conflict-Analysis Study Sarajevo: Friedrich-Ebert-Stiftung)

\begin{tabular}{|l|l|l|}
\hline \multicolumn{1}{|l|}{ 1992: Pre-war } & $\begin{array}{l}\text { 1992-1995: Wartime } \\
\text { society/mentality }\end{array}$ & $\begin{array}{l}\text { 1995-present: } \\
\text { war/Dayton } \\
\text { society/mentality }\end{array}$ \\
\hline $\begin{array}{l}\text { "Brotherhood \& Unity"; } \\
\text { Focus on citizenship-based } \\
\text { identity }\end{array}$ & $\begin{array}{l}\text { Extreme nationalism; } \\
\text { instrumentalization of } \\
\text { religion for ethno-nationalist } \\
\text { purposes; violence, ethnic } \\
\end{array}$ & $\begin{array}{l}\text { Focus on ethnicity/religion- } \\
\text { cleansing }\end{array}$ \\
& & \\
\end{tabular}

\section{The first phase}

The first phase covers the period between the two wars, from 1945. to 1992., when $B \& H$, together with the other five republics (Slovenia, Croatia, Serbia, Montenegro, Macedonia), was a part of the Socialist Federal Republic of Yugoslavia (below Yugoslavia). "Tito's regime" was essentially a communist-socialist dictatorship, which went hand in hand with economic pluralism, freedom of travel, foreign exchange account, and relative intellectual freedoms" (Kivimaki, Kramer \& Pasch, 2012). It arose from the struggle of the Partisans, the ability to provide a quality standard of living, and the position in the world as a bridge between West and East (Kaldor, 1999). The 
Communist Party of Yugoslavia advocated "Brotherhood and Unity" among the Yugoslav peoples, and the notion of Yugoslavism was powerful in modern and secular B\&H.

From the very beginning, i.e. since 1945, the goal of education was the promotion and development of the Socialist state. At the Third Plenum of the Communist Party of Yugoslavia held in 1949, it was defined that the goal of education should be "the formation of a universal educational system as a free construct of socialism, distanced from bureaucracy and stupidity" (Subotić, 1984, p. 112). In 1950, education was based on "scientific materialism" as a means of building a Socialist country (UNESCO, 1950, p. 247). The direct relationship between politics and education was well known and cultivated by Tito. As Filipović stated (1971, p. 512) "the dominance of politics over pedagogy is cultivated and accepted as a normal fact".

The Second World War made a lasting impact on the educational system of Yugoslavia, both in terms of the destroyed infrastructure and the loss of teaching staff. Of the 48,721 teachers throughout Yugoslavia at the beginning of the war, approximately 10,000 were killed or had left the country by the end of the war (Georgeoff, 1982). The Yugoslav government invested heavily in education's reconstruction, realizing that it was a tool for the reconstruction of the war-afflicted country, for its economic growth, improvement of general standards, and promotion of the ideological atmosphere of the time (Soljan, 1991, p. 133). By 1953, $85.5 \%$ of the population had completed four grades of elementary school, while $36.5 \%$ had completed eight grades (Central Intelligence Agency, 1990). By 1963, the percentage of the population with eight grades of elementary education had increased to $46 \%$ (Jemuović, 1964). This growth was in large part due to the educational reforms of 1958, which were accompanied by the adoption of a new General Law on Education. These reforms included the precise definition of the structure and goals of education, incorporating some distinctly Western characteristics that were retained until the break-up of Yugoslavia. The mentioned law was "in line with social development to allow the system to influence new generations to participate in a creative way to the construction of a socialist society" (Živojinović \& Zojica, 1959, p. 469). Through its goals of propagating socialism, social self-government and brotherhood and unity, political influence is visible. At the same time, the above-mentioned Western characteristics are visible through the treatment of students as an active factor in the educational process, and the discussion of all problems of school life and work within the classroom and school community. The new Yugoslav Constitution (1974) contained specific direct provisions on education that were to be applicable throughout Yugoslavia. All education was to be Marxist in its orientation, and serve Yugoslav economic and social objectives, as claimed by Georgeoff (1982). 
The Preamble to the 1974. Constitution stated that: "The system of upbringing and education shall be based on the achievements of modern science, especially of Marxism as the foundation of scientific socialism, and shall be instrumental in training young people for work and self-management and educating them in the spirit of achievements of the Socialist Revolution, the socialist code of ethics, self-management democracy, socialist patriotism, [...] the equality of nations and nationalities and socialist internationalism" (Constitution of Yugoslavia, 1974). The 1974 Constitution also gave recognition to all languages in Yugoslavia: "The language of people and nationalities and their alphabets shall be the same throughout the territory of Yugoslavia" (Constitution of Yugoslavia, 1974, Article 246). This meant that members of all nations and nationalities had a right to instruction in their language, as defined by Article 171 of the Constitution. Accordingly, ten minority languages, in addition to the three main languages - Serbo-Croatian, Macedonian and Slovenian - were used in teaching (Farmerie, 1972). The objectives for education in Yugoslavia, in general, applied to elementary education and included the following: to increase and broaden Marxist ideology and orientation in education, to increase the relationship of education to work, partially through a more intensive program of labour education and political training, and to increase the active participation of the school in community activities, particularly in community cultural activities and sociopolitical work (Georgeoff, 1982).

As for B\&H, it lagged behind other parts of Yugoslavia in terms of educational development (Tomich, 1963, cit. in Lanahan, 2017). However, economic development intensified very quickly in $\mathrm{B} \& \mathrm{H}$, as a result of industrialization and the transfer of labour from farms to factories, resulting in an increased requirement for education that was accessible, compulsory and free for all citizens. The curriculum in primary schools included the social sciences, arts, physical and music education, mathematics, foreign languages, mother tongue, and vocational studies (Farmerie, 1972), while the curriculum in secondary schools varied depending on the type of school.

In June 1945, 97,116 students in Bosnia and Herzegovina attended 684 primary schools, which employed 1,288 teachers (Dizdar, 1996). By 1961, the illiteracy rate of the population of $\mathrm{B} \& \mathrm{H}$ had fallen to $32.5 \%$, but this was still considerably higher than the national average of $19.7 \%$ (Federal Bureau of Statistics, 1961). As a way to combat such a flawed statistic, the slogan of the Bosnia-Herzegovinian government became: "A thousand new schools" (Dizdar, 1996), and by the 1960s, B\&H had 2,948 schools, almost achieving the policy goal (Šušnjara, 2015). Also, in that period, B\&H lacked a sufficient number of teaching staff and had to introduce teachers from other parts of Yugoslavia, mostly from Serbia and Montenegro. 
After the fall of communism in the countries of Eastern Europe, Yugoslavia was economically abandoned by the United States, the economy collapsed, and ethnic tensions arose. In 1991, the independence of Slovenia, Macedonia and Croatia was declared, with Bosnia and Herzegovina following in 1992. Later, in 2006, Montenegro ended its union with Serbia, and finally, Kosovo declared independence from Serbia in 2008. As the most ethnically diverse part of Yugoslavia, upon declaring independence, Bosnia and Herzegovina almost immediately fell into a state of war (Duilović, 2004, p. 21).

To understand all the sensitivity of the conflict that befell the state, the period of war from April 1992 to December 1995 will be considered below. Although there is no intention here of explaining the war itself, the second phase that follows will identify the dividing lines within the population, and also consider the motives for the divisions that began to appear in the education system at the time immediately preceding the outbreak of war in $\mathrm{B} \& \mathrm{H}$.

\section{The second phase}

The second phase involves a period of war, from 1992. to 1995, that "is characterized by extreme nationalism, violence, and war incidents" (Kivimaki, Kramer \& Pasch, 2012). At this stage of Bosnia and Herzegovina's existence, there was a visible explosion of nationalism; not only in B\&H but also in other Central and South-eastern European countries. One attempt to explain the causes of ethnic or national violence leads to the conclusion that their roots should be sought in complex historical, religious and social factors (Clark, 2002; Skilling, 1966). Also, political leaders encouraged national discord and violence to continue to pursue their interests (Clark, 2002; Lewin, 1988). In the case of $\mathrm{B} \& \mathrm{H}$, a combination of these two approaches could be applied: ethnicity is vital for people, and when the prevailing ideology of 'Yugoslavism' faded, national political leaders very consciously introduced a 'culture of fear' to their ethnic group, using national propaganda to achieve their interests.

In March 1992, B\&H, the most ethnically heterogeneous Yugoslav republic, declared independence, with international recognition following in its wake, after which war between the three dominant groups became almost inevitable. Strong ethnic instrumentalizations influenced war and crime (Nettelfield, 2010). Formally, the war in B\&H began on April 6th 1992, although conflicts in some parts of the country began much earlier. 
At the beginning of autumn 1992, three separate curricula were implemented. One was Serbian, adapted from the Republic of Serbia, another Croatian, which was imported from Croatia, with the third being Bosnian, and mainly a modified version of the pre-war education system of the Republic of B\&H (The Bosnian Institute, 1993, pp. 4-9). In that period of the disintegration of Yugoslavia, all the countries that emerged had one goal; to create conditions for strengthening their national characteristics. This meant that the previous education system, which was unitary across all six countries, should be replaced by six new systems that would be unique to each state. According to Pašalić-Kreso (2008), the creators of such educational policies focused more on establishing differences from others than on providing the best possible education for their children. The results, as well as the holding of multi-party elections in $\mathrm{B} \& \mathrm{H}$, among other things, meant the affirmation of existing processes in all areas of life, including education. Educational policies with a national slant aimed at strengthening national identity by affirming the national language and literature, national history, and religion became very desirable and highly applicable in places where one ethnic group represented a dominant majority. ${ }^{4}$

The education system in certain parts of the country depended on the army that conquered the area. Thus, in the areas conquered by the Army of Republic of Srpska, textbooks from Serbia were used, while textbooks from Croatia were widely used in those areas where the Croatian Defence Council had authority. However, what is especially characteristic for the analysis of the education system within the second phase is the fact that the newly formed ethnonational government of the territories controlled by the Army of Republic of Srpska set itself the first task of adopting the 1993 Law on Universities. By this Law, the University of Banja Luka has declared the state university of the Republic of Srpska. Such an endeavour can be understood as the desire of the then-government to use education as a fundamental means of fulfilling ethnonational goals by creating an ethnonational identity and its successful selfexistence. Furthermore, the Academy of Science and Art of Republic of Srpska was also established by decree in 1993, amid the war. However, it was not officially constituted until 1996 as a physical entity financed from the public budget (Academy of Science and Art of Republic of Srpska, 2020).

4 "Overnight, the Serbo-Croatian or Croato-Serbian language and bilingual speech variants disappear and are replaced by Serbian, Croatian and Bosnian, with the corresponding Ekavian, ljekavian speech variants, and a speech variant with accentuated use of the sound h" (Peco, 2008, p. 287). 
Something similar happened at the same time upon the territories collectively known as Herceg-Bosna. Croatian flags in schools, and curricula and textbooks imported from neighbouring Croatia. An example that highlights the above is the school in Usora, near Tešanj, where Croatian teachers took all Croat children outdoors and held classes in the yard to separate them from the "others". A TV station interviewed students who attended such classes by chance immediately after the end of the war. From their answers, it can be seen that they believed that their capital was Zagreb and that their president was Franjo Tuđman (Pašalić-Kreso, 2008). This was a real proof of the consequences of the use of textbooks from neighbouring countries on education in Bosnia and Herzegovina. Immediately after the end of the war, Croatian representatives demanded separate schools, with the pretext of protecting the cultural identity and interests of Croats in Bosnia and Herzegovina (Magas, 1998, p. 20).

The territory under the control of the Army of B\&H used curricula identical to those before the war, with the only difference being that affiliation with Bosnia and Herzegovina was more affirmed. Pašalić-Kreso (2008) states that the Bosnian education system also broadly promoted patriotism and introduced Islamic religious education in schools, this being found unacceptable by other ethnic groups at the time and undeniably presenting a form of discrimination.

In essence, the conclusion is that the influence of national policies and parties on education and the creation of three national education systems is highly evident. None of those mentioned above education systems paid a great deal of attention to building citizens and developing awareness of belonging to the state.

\section{The third phase}

The third phase began with the signing of the Dayton Agreement, ${ }^{5}$ when peace was established in 1995. Any systemic view of education in the post-war period of B\&H must begin with an explanation and analysis of the structure and implementation of the peace agreement because the main challenge facing $\mathrm{B} \& \mathrm{H}$ in the post-war period is the structure of the Dayton Accords. This agreement was strong enough to preserve

${ }^{5}$ The Dayton Peace Agreement, which formally ended the war upon the territory of the Republic of B\&H, was initialled at the Wright-Patterson Air Force Base in Dayton, Ohio, in November 1995, and signed in December of the same year in Paris. This agreement completed the process of reintegration and disintegration of the country; society, as a supposed whole, was divided within the framework of forced unity, because the war ended without winners and losers (Kapo, 2012) 
peace, while, on the other hand, it was flexible at the same time, enabling the necessary reforms of the police, defence, etc." (Office of the High Representative $\mathrm{OHR}, 2005)$. However, the primary shortcoming of the agreement was the emphasis on a truce, leaving B\&H in a 'frozen conflict' (Perry \& Keil, 2012), where the issues that caused the conflict remained unaddressed, with the territory being divided between occupying forces (Magas, 1998). On the other hand, concerning education and other cultural policies, much room was left for discrimination and differing interpretations.

The unusual state structure created by the Dayton Peace Agreement has several adverse effects on the education sector. Pašalić-Kreso (2008) states that "from the very beginning, the Dayton Agreement created a decentralized, asymmetric and defective system of governance in education, which neglected the unity of education policy, common goals in education, common values, and positive and patriotic feelings for the country and homeland". The Constitution of B\&H, which is an integral part of the Dayton Peace Agreement, i.e. its Annex IV, explicitly states that education is not the competence of the state. ${ }^{6}$

The education system of B\&H, if it can be called a system at all, is highly complex, fragmented and decentralized, and lacking any fair horizontal and vertical hierarchy. Since its birth as a sovereign entity, B\&H has had a decentralized, asymmetric and flawed education management system that has undermined unity in education policy, common educational goals, shared values, and positive and patriotic feelings for its country and homeland (Pašalić-Kreso, 2008). This situation is the result of a multilayered government structure, with 13 different ministries of education; one for each of the two entities, each of the ten cantons, and a separate ministry for Brčko District. Such a structure has resulted in a "huge increase in bureaucracy in education and is a costly and inefficient system for such an impoverished country" (Pašalić-Kreso, 2008, p. 361), as B\&H was, and unfortunately remains today. Thus, "Bosnia and Herzegovina - a country of about 4 million people - has a total of 13 ministries responsible for education" (Clark, 2010, p. 345). This extreme decentralization makes it impossible to

${ }^{6}$ Article III, paragraph 1. of the Constitution of B\&H defines the competencies of the institutions of $\mathrm{B} \& \mathrm{H}$. The following matters are the responsibility of the institutions of Bosnia and Herzegovina: "(a) Foreign Policy; (b) Foreign trade policy; (c) Customs policy; (d) Monetary policy as provided for in Article VII; (e) Financing the institutions and international obligations of Bosnia and Herzegovina; (f) Immigration, refugee and asylum policies and regulations; (g) Enforcement of international and inter-entity criminal law, including relations with INTERPOL; $(\mathrm{h})$ Installation and operation of common and international communication devices; (i) Adoption of inter-entity transport regulations; (j) Air traffic control. (OHR, 2020) 
implement any policies for building a single state. Nineteen years ago, in 2001. to be precise, the Organization for Economic Cooperation and Development (2001) explained that education in B\&H had become a "hostage of latent nationalism."

After seven years without coordination at the state level, in 2003, the Ministry of Civil Affairs was given the role of coordinating and supervising education in B\&H (UNESCO, 2015), with the adoption of the Law on Ministries and Other Administrative Bodies of B\&H (2016), which defines the competences of the state-level Ministry of Civil Affairs. Although the Ministry was given its role relating to this in 2003, the regulation of the education sector remained in the hands of the entities, cantons and Brčko District.

Such a decentralized education system poses a significant problem for the creation of uniform education policies, and thus generates many problems related to the determination of competences and responsibilities, and the coordination of activities. According to Branković and Arapović (2010), the essential characteristics of the situation in the education sector in B\&H can be summarized as follows: a large number of laws regulating the education sector; the high degree of politicization present in the education system, both in management and through curricula; a high nominal share of education funds compared to GDP, but also an insufficient level of financial resources for quality education; complete neglect of scientific research work as part of the educational process; lack of adequate educational standards; curricula incongruent to the practice of EU member states; outdated equipment, lack of trained staff.

Namely, the problems present in education in $\mathrm{B} \& \mathrm{H}$ are multiple. Primarily during the post-war mass return, returnees in many places were faced with a ban on access to their children's schools. Temporary solutions to alleviate this included special schools for returnees being established within pre-existing school buildings. However, local authorities continuously blocked attempts to further fit into the new environment, leading to the formation of organizational units known as "two schools under one roof".

However, this type of school is only one of the indicators of problems that occur across the entire territory of B\&H. Parents are forced to choose between assimilating their children in local schools or transporting them to schools in (often) distant settlements with another, national majority group. For parents who lack such an opportunity, the introduction of an alternative curriculum and textbook for the national group of subjects was made possible after the signing of the Interim Agreement on Meeting the Special Needs and Rights of Returnee Children in 2002. However, the study of subjects from the national group of subjects is, in practice, generally offered only in certain places, where large numbers of returnees and their descendants live (except Brčko 
Criminal Justice Issues - Year XX, Issue 5, 2020.

Halilović-Kibrić - Security Aspects of Fostering the Dominance of Politics Over Education in Bosnia and Herzegovina

District of $\mathrm{B} \& \mathrm{H}^{7}$ ). Despite the Interim Agreement's insistence on finding lasting solutions for all children, education authorities have so far failed to join forces to fulfil this obligation (Organization for Security and Co-operation in Europe - OSCE, 2012).

Many international bodies have analysed this issue and made various recommendations (The European Commission against Racism and Intolerance (ECRI), the OSCE Mission to Bosnia and Herzegovina, and the UNDP, among others). However, the situation has remained unchanged, as evidenced by the findings of the latest available European Commission against Racism and Intolerance (ECRI) report on the current situation. Concerning the education sector, which should play a key role in overcoming inter-ethnic tensions, ECRI notes that none of its 2017 recommendations has been implemented and that the situation remains broadly unchanged. Except for the District of Brčko, and despite legal obligations, as well as previous commitments to integrate education, public schools in B\&H are still not organized as multicultural, multilingual, open and inclusive institutions for all children. Ethnic segregation, based on the politicized notion of mother tongue education, is still present. The emergence of "two schools under one roof" is the most obvious form of this problem (Council of Europe, 2020).

Despite previous ECRI priority recommendations to resolve all remaining cases of this type of school, and the decision of the Supreme Court of the Federation of B\&H in November $2014,{ }^{8}$ the authorities informed ECRI that this practice is still maintained in

7 In 1999, after previously being separated between the jurisdiction of the Federation of B\&H and the Republic of Srpska, Brčko became a separate district, after arbitration finally resolved a situation that had, until that point, prevented reconciliation and prevented refugees from returning to the area. However, not everything went smoothly in the field of education in this part of B\&H. Students who declared themselves as Serbs in 2000 caused significant unrest following their request for separate schools being rejected. However, the local law on education, adopted in 2001, provided for the gradual integration of schools and the harmonization of curricula. Similar to other parts of $\mathrm{B} \& \mathrm{H}$, education reform had a plan to "integrate District schools, harmonize their curricula, and clean textbooks and teaching materials of offensive content" (International Crisis Group, 2003, p. 10). The model currently applied in the District includes the right of each student to choose the language by which to express themselves in school, as well as the right to choose which language is declared on their diploma transcript, and special attention is paid to the ethnic representation of teachers.

${ }^{8}$ Supreme Court of the Federation of B\&H, Judgment no. 580 Ps 08565313 Rev, 29 August 2014 (See more at http://www.vasaprava.org/wp-content/uploads/downloads/2014/11/Vrhovnisud-Federacije-BiH-odluka- po-reviziji-dvije-postoC5postoA1kole-pod-jednom-krovom_01.pdf, accessed 4 September 2020) 
many schools in the Central B\&H -Neretva Cantons of the Federation. Separation of Bosniak, Croat and Serb school children into ethnically homogeneous schools remains a common practice throughout the country, both in the Republic of Srpska and the Federation, and no steps have been taken to end this, despite the European Commission against Racism and Intolerance 2017 recommendations (Council of Europe, 2017).

The possibility of establishing integrated education is shown by the example of the autonomous Brčko District. There are no longer divided in mono-ethnic schools in the District, with the joint teaching of children from different ethnic communities having been successfully implemented. Teachers in the Brčko District attend training to enable students and teaching staff to use each of the three official languages. In its report, however, the ECRI states that, already in 2014, during talks with the education authorities of the Republic of Srpska and various cantons of the Federation, a strong and politically motivated rejection of the idea that the Brčko District education system could be seen as a model for future integration was evident.

Outside the Brčko District, the positive steps taken by some schools - such as the grammar school in Mostar visited by the ECRI delegation - are primarily limited by the existing legal framework for the education sector, which upholds a separate languagebased - and, by extension, ethnic-affiliation-based - classroom structure in the Federation and RS. Mostar's grammar school has made dedicated efforts to improve the situation, not only by initiating an administrative merger (one principal, a unified teaching staff, one Student Council and one Parents' Council) but also organized, as far as possible, joint activities for students, such as art projects, sports, festivities, and school trips. ECRI welcomes such initiatives but also points out that they are not sufficient in number, and that they continue to be exceptions, rather than the rule, across the state.

In 2017, the ECRI recommended the full implementation of a standard core curriculum across the country. The authorities informed ECRI that in some Cantons of the Federation of Bosnia and Herzegovina (one of the country's two entities, the other being the Republic of Srpska) activities related to the standard core curriculum have been implemented. However, these consisted of pilot projects and training activities. While such preparatory work is useful, it is not the full-scale application of the standard core curriculum that ECRI and other relevant bodies have repeatedly recommended. However, political objections to curriculum alignment remain strong, especially concerning the so-called 'national subject group', namely history, mother tongue and literature, geography, art and music. 
A devastating fact is that, instead of abolishing separate schools, attempts have been made by authorities to extend discrimination to other schools. This problem was particularly pronounced in the summer of 2016 when the Central Bosnia Canton Government tried to divide students in Jajce. ${ }^{9}$

However, while schools that operate on the principle of "two schools under one roof" are seen as a problem in $\mathbf{B} \& H$ on the one hand, on the other, an equally significant problem persists, that of ethnically homogeneous schools that do not provide opportunities for children and youths to learn about the traditions, religions and cultures of their co-citizens. Also, in most cases, returnee minority populations of any ethnic group face significant problems within the education system. The ECRI report is just one of several that addresses this topic and underlines the importance of this issue, but the authorities in $\mathrm{B} \& \mathrm{H}$ have taken no steps to implement recommendations addressed, and therefore no progress towards abolishing such practices has been made.

This creates a dire situation for $\mathrm{B} \& \mathrm{H}$, a post-war multi-ethnic and multi-confessional state, in which everyone should be equal in terms of the opportunities provided by education. Breaking down barriers between children and eliminating discriminatory activities are essential factors for the well-being of children and youth in $B \& H$, as well as for establishing a future in which everyone has the opportunity to attend classes with peers and be educated in a pleasant, well-meaning and safe environment.

\section{CONCLUSION}

If we summarize the current situation in the education system of Bosnia and Herzegovina, we conclude that education is not geared toward the function of social integration but, according to Perry (2015), a mere "continuation of the war by other means." The current ethnically determined and segregated education system is a consequence of the turbulent past that was created and continued with the goal of ethnic crystallization and determination. First of all, the paper shows and proves a direct relationship between politics and education at the time when Bosnia and Herzegovina was a part of Yugoslavia. Such a relationship was well known and

\footnotetext{
${ }^{9}$ At the beginning of the summer of 2016, the government of the Central Bosnia Canton decided to build another high school in Jajce, in order to create conditions for the education of high school students to be divided along ethnic lines. However, the students rebelled against the decision of the elected politicians, with the decision eventually being reversed, showing the (occasional) success of grassroots activism in B\&H as well. (Halimić, 2016, August 8).
} 
cultivated by Tito. As Filipović stated (1971, p. 512) "the dominance of politics over pedagogy is cultivated and accepted as a normal fact". The General Law on Education of 1958 clearly defined the structure and goals of education, incorporating some distinctly Western characteristics that were in force until the break-up of Yugoslavia. This law was "in line with social development so that the system should have influenced new generations to participate in a creative way in building a socialist society" (Živojinović \& Zojica, 1959, p. 469). Political influence is visible through the goals that propagated Socialism, social self-governance and brotherhood and unity. At the same time, the above-mentioned Western characteristic is visible in the treatment of students as an active factor in the educational process, and their inclusion in discussions of all problems of school life and work within the classroom and school community (Živojinović \& Zojica, 1959, p. 474).

In the subsequent period, during the period of disintegration of the Socialist Federal Republic of Yugoslavia, all newly independent states had one goal: to create conditions for strengthening their national characteristics. This meant that the previous education system, which was unitary across all six countries, needed to be replaced by six new systems that would be unique to each state. According to Pašalić-Kreso (2008), the creators of such educational policies focused more on trying to achieve a difference from others than on providing the best possible education for their children. The education system in some parts of Bosnia and Herzegovina depended on the army that controlled the area. The conclusion is that, in this period, the influence of national policies and parties on education and the creation of three national education systems is evident. None of those above education systems paid a great deal of attention to developing citizens and their awareness of belonging to the state.

Regarding the final period analysed, that of post-conflict Bosnia and Herzegovina, the entire education system, as well as all the problems within it, have been subjected to more significant analysis. Many international bodies have tried for years to define and highlight the significant shortcomings of the education system, but progress in their rectification has been limited. Ethnic segregation, based on the politicized notion of mother tongue education, is still present. The emergence of "two schools under one roof" is the most obvious manifestation of this problem. However, while schools that operate on the principle of "two schools under one roof" are seen as a problem in Bosnia and Herzegovina on the one hand, on the other, an equally significant problem persists, that of ethnically homogeneous schools that do not provide opportunities for children and youths to learn about the traditions, religions and cultures of their cocitizens. 
It should be concluded that all authorities and ruling governments in the periods of interest in this work, in the $20^{\text {th }}$ and $21^{\text {st }}$ centuries, have been acutely aware that the ease of their rule and the reproduction of the ruling relationship depends to a large extent on the nature of education, and have carefully crafted curricula and educational programs to their agendas and aims. Today's reality confirms the truth of this in Bosnia and Herzegovina, whereby national leaders wave educational programs in front of the public as being vital national interests.

Finally, education, as a vital segment of public life and civil society in post-conflict Bosnia and Herzegovina, needs reform, in order to achieve post-conflict justice and peace. Given the persistent ethnic polarization, all countries in the region could make fair use of the Council of Europe's expertise in this sector, thus improving their education systems, primarily in the fields of human rights, democratic citizenship and cultural diversity.

\section{REFERENCES}

1. Abazović, M. (2012). Drzavna bezbjednost. Fakultet kriminalističkih nauka.

2. Academy of Science and Art of Republic of Srpska (2020). Foundation, establishment and status of the Academy. https://www.anurs.org/en/item/c429

3. Azinović, V., Bassuener, K., \& Weber, B. (2012). Procjena potencijala za obnovu etničkog nasilja u Bosni i Hercegovini: Analiza sigurnosnih rizika. Atlanska Inicijativa i Univerzitet u Sarajevu, Fakultet političkih nauka.

4. Branković, N., \& Arapović, A. (2010). Obavezno srednje obrazovanje u BiH: ambijent i perspektive. Centri civilnih incijativa.

5. Bush, K., \& Saltarelli, D. (2000). The Two Faces of Education in Ethnic Conflict, United Nations Children's Fund, Innocenti. United Nations Children's Fund, Innocenti Research Centre.

6. Central Intelligence Agency. (1990). History of Yugoslav education. U 1990 world factbook. Washington, DC: Central Intelligence Agency.

7. Clark, N. (2010). Education in Bosnia and Herzegovina: the case for root-andbranch reform. Journal of Human Rights, 9, 342-362.

8. Clark, T. D. (2002). Beyond post-communist studies: political science and the new democracies of Europe. M.E. Sharpe.

9. Constitution of the Federal Republic of Yugoslavia (1974). https://www.worldstatesmen.org/Yugoslavia-Constitution1974.pdf

10. Council of Europe (2017). Third report on Bosnia and Herzegovina (fifth monitoring cycle). https://rm.coe.int/third-report-on-bosnia-andherzegovina/16808b5602 
11. Council of Europe (2020). ECRI conclusions on the implementation of the recommendations in respect of Bosnia and Herzegovina subject to interim follow-up. https://rm.coe.int/ecri-conclusions-on-the-implementation-of-therecommendations-in-respe/16809cde0e

12. Davies, L. (2004). Education and conflict: Complexity and chaos. Routledge.

13. Dizdar, S. (1996). Razvoj i perspektiva obrazovanja nastavnika u Bosni $i$ Hercegovini. Ministarstvo obrazovanja, nauke, kulture i sporta FBiH.

14. Duilović, D. (2004). Strategy and quality in education: Bosnia and Herzegovina. The World Bank.

15. Farmerie, S. (1972). Education in Yugoslavia. The Clearing House, 47(3), 145-149.

16. Filipović, N. (1971). Odnos pedagogije i politike u vremenu od 1945-1970. Naša škola, 9(10), 511-525.

17. Fond otvoreno društvo Bosne i Hercegovine. (2007). Obrazovanje u BiH: čemu učimo našu djecu? Fond otvoreno društvo Bosne i Hercegovine.

18. Georgeoff, J. (1982). The educational system of Yugoslavia. US Department of Education, International Education Programs.

19. Halimić, E. (2016, August 8). Mladi pobijedili sistem: U Jajcu neće biti odvojenih škola! Dnevni avaz. https://avaz.ba/vijesti/teme/250153/mladi-pobijedilisistem-u-jajcu-nece-biti-odvojenih-skola

20. Halmi, A. (1999). Temelji kvantitativne analize u društvenim znanostima. Alinea.

21. Jemuović, R. (1964). Education in Yugoslavia. Međunarodna politika.

22. Kaldor, M. (1999). New and Old Wars. Organized Violence in a Global Era. Stanford University Press.

23. Kapo, M. (2012). Nacionalizam i obrazovanje. Program podrške obrazovanju Fond otvoreno društvo Bosne i Hercegovine.

24. Kivimaki, T., Kramer, M., \& Pasch, P. (2012). Dinamika konflikta u multietničkoj državi Bosni i Hercegovini - Studija analize konflikta u pojedinim zemljama. Friedrich-Ebert-Stiftung.

25. Lanahan, B. (2017). A Brief History of Bosnia and Bosnian EducationBrotherhood and Unity. In : B. Lanahan. Post-Conflict Education for Democracy and Reform (pp-1-28). Springer

26. Law on Ministries and Other Administrative Bodies of Bosnia and Herzegovina, Official Gazette of B\&H, No. 5/03, 42/03, 26/04, 42/04, 45/06, 88/07, 35/09, 59/09, 103/09, 87/12, 6/13, 19/16 (2016).

27. Lewin, M. (1988). The Gorbachev phenomenon: a historical interpretation. Radius.

28. Magas, B. (1998). Question of survival: A common education system for BosniaHerzegovina. The Bosnian Institute.

29. Nettelfield, L. (2010). Courting democracy in Bosnia and Herzegovina: The Hague Tribunals Impact in a postwar state. Cambridge University Press. 
30. OECD. (2003). Thematic Review of National Policies for Education-Bosnia and Herzegovina. OECD. https://dx.doi.org/10.1787/9789264100725-en

31. OECD (2015) States of Fragility 2015, Meeting Post-2015. OECD. http://www.oecd.org/dac/states-of-fragility-2015-9789264227699-en.htm

32. Office of the High Representative -OHR (2020). Constitution of Bosnia and Herzegovina.http://www.ohr.int/ohr_archive/remarks-by-the-highrepresentative-paddy-ashdown-at-a-conference-on-the-balkans-and-euroatlantic-integration-beyond-dayton-at-the-crossroads-bihs-journey-fromdayton-to-brussels/

33. Office of the High Representative -OHR (2005). Remarks by the High Representative, Paddy Ashdown at a conference on the Balkans and EuroAtlantic integration: beyond Dayton: "At the crossroads: B\&H's journey from Dayton to Brussels"

34. OSCE. (2006). Report on Challenges and Responses ti Hate-Motivated Incidents in the Region. OSCE. http://www.osce.org/odihr/21629

35. OSCE. (2018). "Dvije škole pod jednim krovom" Najvidjiviji primjer diskriminacije u oblasti obrazovanja u bosni i Hercegovini. Misija OSCE-a u Bosni i Hercegovini.

36. OSCE BiH Ured OSCE-a za demokratske incijative i ljudska prava (ODIHR) (2010) Razumijevanje krivičnih djela počinjenih iz mržnje: Priručnik za Bosni u Hercegovinu.http://www.oscebih.org/documents/osce_bih_doc_201012271234 2149bos.pdf

37. Pašalić-Kreso, A. (2005). Višegodišnja mutacija i rezistentnost ratnog virusa podjele u bosanskohercegovačkom obrazovanju. In: A. D. Sejmenović, Bosna i Hercegovina na putu ka modernoj državi?Perspektive i prepreke. Heinrich Böll Stiftung.

38. Pašalić-Kreso, A. (2008). The War and Post-war Impact on the Educational System of Bosnia and Herzegovina. International Review of Education, 54, 353374.

39. Peco, A. (2008). Obrazovanje i nacionalna emancipacija. Univerzitet "Džemal Bijedić" Nastavnički fakultet.

40. Perry, V. (2015). Suprostavljanje kultivisanju ekstremizma u Bosni i Hercegovini: Argumenti za sveobuhvatnu reformu obrazovanja. Školegijum.

41. Perry, V. \& Keil, S. (2012). The OSCE mission in Bosnia and Herzegovina-Testing the limits of ownership. Nationalities Papers, 41, 371-394.

42. Skilling, G. (1966). Interest groups and communist politics. World Politics, 18(3), 435-451.

43. Smith, A. (2005). Education in the twenty-first century: Conflict reconstruction and reconciliation. A Journal of Comparative and International Education, 35 (4), 373-391. 
44. Soljan, N. N. (1991). The saga of higher education in Yugoslavia: Beyond the myths of a self-management socialist society. Comparative Education Review, 35(1), 131-153.

45. Subotić, G. (1984). Pedagoške misli Rodoljuba Čolakovića. Naša škola, 3(4), 232240.

46. Šušnjara, S. (2015). Development of school systems and pedagogy in Bosnia and Herzegovina from the period after World War II to the 1970s. Journal of Contemporary Educational Studies/Sodobna Pedagogika (66), 75.

47. The Bosnian Institute (1993) Question of Survival - A Common Education System for Bosnia-Herzegovina. The Bosnian Institute.

48. UNESCO. (1950). International yearbook of education 1950. International Bureau of Education.

49. UNESCO. (2005). Knowledge societies, human security, human rights and the fight against poverty. UNESCO.

50. Živojnović, P., \& Zojica, L. (1959). School reform in Yugoslavia (Yugoslavia's new Education Act). International Review of Education, 5(4), 469-477.

\section{About the author}

Nerma Halilović Kibrić, PhD, senior teaching assistant, Faculty of Criminalistics, Criminology and Security Studies, University of Sarajevo.

E-mail:nhalilovic@fkn.unsa.ba 